\title{
THE NEXUS BETWEEN OIL PRICES AND AIRLINES STOCK RETURNS IN BORSA ISTANBUL DURING THE COVID-19 PANDEMIC
}

\author{
DOI: 10.17261/Pressacademia.2021.1518 \\ PAP- V.14-2020(44)-p.156-157
}

\section{Caner Ozdurak}

Yeditepe University, Financial Economics Department, Istanbul, Turkey cozdurak@gmail.com, ORCID: 0000-0003-0793-7480

To cite this document

Ozdurak, C., (2020). The nexus between oil price and airlines stoc returns in Borsa Istanbul during the Covid-19 pandemic. PressAcademia Procedia (PAP), 14, 156-157.

Permemant link to this document: http://doi.org/10.17261/Pressacademia.2020.1518

Copyright: Published by PressAcademia and limited licenced re-use rights only.

\begin{abstract}
Purpose- The impact of crude oil on the industries is different based on the dependency of the related business line. Thus, airlines are usually sensitive to the changes in crude oil price changes since is composes a considerable proportion of the operational costs. This study distinguishes itself from the majority of the literature that it focuses on analyzing the crude oil price airlines stock prices and transportation index in Borsa Istanbul and discuss the impact of the change in crude oil prices on them both in the long-run and specifically in the covid-19 pandemic.

Methodology- In our study, the return spillover effect is determined by the mean equation set as vector autoregressive model (VAR model) while the volatility spillover effect between crude oil price and the stock price of airlines companies is determined via the variance equation set as the VECH-TARCH model to catch the asymmetric news impact as well.

Findings- According to the model results the volatility spillover effect between crude oil price and airlines' stock price is more significant compared to the return spillover effect. In the short term the volatility spillover effect between crude oil price and Turkish Airlines stock price is more significant compared to Pegasus Airlines (PGSUS) and transportation index. Secondly, in the long run the volatility spillover effect between crude oil prices and all three assets are strongly significant. Third, there is no asymmetric news impact between crude oil prices and Pegasus Airlines stocks and transportation index. However, asymmetry exists for Turkish Airlines stocks. Good news from crude oil markets to Turkish Airlines increase the volatility as well.

Conclusion- According to the model results the volatility spillover effect between crude oil price and airlines' stock price is more significant compared to the return spillover effect. transportation index and oil prices. Only in the Covid-19 period there is an influence between Turkish Airlines and transportation index returns with Dubai and WTI oil prices.
\end{abstract}

Keywords: Spillover, airlines, VAR-VECH-TARCH, crude oil, Turkish Airlines, Pegasus, contagion effect JEL Codes: C58, G14, L93, E44

\section{REFERENCES}

Arouri, M.E.H., Lahiani, A., Nguyen, D, K., (2011). Return and volatility transmission between world oil prices and stock markets of the GCC countries. Economic Modelling. 28(4), 1815-1825

Bouri, E., (2015). Oil volatility shocks and the stock markets of oil-importing MENA economies: A tale from the financial crisis. Energy Economics, 5(C), 590-598.

Ding, Z., Liu Z., Zhang, Y. and Long, R. (2017). The contagion effect of international crude oil price fluctuations on Chinese stock market investor sentiment. Applied Energy, 187, 27-36.

Du, L., He, Y. (2015). Extreme risk spillovers between crude oil and stock markets. Energy Economics, 51(C), 455-465.

Engle, R, F., (1982). Autoregressive conditional heteroscedasticity with estimates of the variance of United Kingdom inflation. Econometrica, 50, 987-1007.

Engle, R, F., Victor K. Ng, (1993). Measuring and testing the impact of news on volatility. Journal of Finance, 48, 1749-1778. 
Engle, R, F., Kroner, K, F. (1995). Multivariate simultaneous generalized ARCH. Econometric Theory, 11(1), $122-150$.

Gillen, D, and Lall, A, (2003). International transmission of shocks in the airline industry. Journal of Air Transport Management, 9, 37-49.

Glosten, L. R., R. Jagannathan, and D. E. Runkle. (1993). On the Relation between the expected value and the volatility of the nominal excess returns on stocks. Journal of Finance $48,1779-1801$.

Gomes, M, and Chaibi, A. (2014). Volatility Spillovers Between Oil Prices and Stock Returns: A Focus on Frontier Markets. Post-Print hal02314397, HAL.

Hatty, H., (2002). Airline strategies against crises. Presentation at 5th Hamburg Aviation Conference. 14 February, Hamburg.

Jones, C., M. and Kaul, G. (1996). Oil and the stock markets. Journal of Finance, 51(2), 463-491.

Malik, F. and Hammoudeh, S. (2007). Shock and volatility transmission in the oil, US, and Gulf equity markets. International Review of Economics and Finance,. 16(3), 357-368.

Miller, J.I. and Ratti, R.A. (2009). Crude oil and stock markets: Stability, instability, and bubbles. Energy Economics, 31(4), 559-568.

Mohanty, S, K. and Nandha, M, (2011). Oil risk exposure: the case of the U.S. oil and gas sector. Financial Review, 46(1), 165-179.

Narayan, P, K., Sharma, S, S., (2011). New evidence on oil price and firm returns. Journal of Banking \& Finance, 35(12), 3253-3262.

Liu, Z, Ding, Z, Li, R, Jiang, X, Wu, and Lv, T. (2017). Research on differences of spillover effects between international crude oil price and stock markets in China and America. Natural Hazards: Journal of the International Society for the Prevention and Mitigation of Natural Hazards. Springer; International Society for the Prevention and Mitigation of Natural Hazards, 88(1), 575-590.

Ling, S., \& McAleer, M. (2003). Asymptotic theory for a vector ARMA-GARCH model. Econometric Theory, 19(2), 280-310.

Phan, D, H, B., Sharma,S, S,. and Narayan, P, K, (2015). Oil price and stock returns of consumers and producers of crude oil. Journal of International Financial Markets, Institutions and Money, 34(C), 245-262.

Reboredo, J.C., (2015). Is there dependence and systemic risk between oil and renewable energy stock prices? Energy Economics, $48,32-45$. Soyemi, K.A., Akingunola, R.O.O., Ogebe, J., (2018). Effects of oil price shock on stock returns of energy firms in Nigeria. Kasetsart J. Soc. Sci. Uddin, S., G., Hernandez, A., J, Shahzad, H., J., S., and Kang, H., S., (2020). Characteristics of spillovers between the US stock market and precious metals and oil. Resources Policy, 66, 101601.

Ulusoy, V., Ozdurak, C., (2018). The impact of oil price volatility to oil and gas company stock returns and emerging economies. International Journal of Energy Economics and Policy, 8(1), 144-158.

Turkish Airlines March 2020 Traffic Results, reached on 18.06.2020 from https://investor.turkishairlines.com/documents/march-2020traffic_web.pdf

Pegasus Airlines March 2020 Traffic Results, reached on 18.06.2020 from http://www.pegasusinvestorrelations.com/medium/image/march2020-traffic-data_966/view.aspx 